\title{
PENERAPAN MODEL PEMBELAJARAN TUTOR SEBAYA PADA MATA PELAJARAN SOSIOLOGI
}

\section{Ningrum Pusporini Anggorowati}

SMA Muhammadiyah Kudus, Jawa Tengah, Indonesia

\section{Info Artikel}

Sejarah Artikel:

Diterima Desember 2010

Disetujui Januari 2011

Dipublikasikan Maret 2011

\section{Keywords:}

model learning;

peer tutor;

sociology subject.

\begin{abstract}
Abstrak
Tujuan penelitian ini adalah untuk mengetahui pelaksanaannya model pembelajaran tutor sebaya (peer teaching) di SMAN I Brebes. Subjek dalam penelitian ini adalah guru sosiologi kelas XI IPS 1 dan siswa kelas XI IPS 1 . Hasil penelitian menunjukkan peer teaching memerlukan persiapan yang matang, dan setiap tahap pelaksanaan hendaknya dievaluasi untuk mendapatkan hasil yang baik. Faktor pendukung dalam pelaksanaan model pembelajaran tutor sebaya antara lain yaitu adanya interaksi antara guru dengan siswa, minat belajar siswa cukup tinggi, guru dan siswa lebih akrab dalam kegiatan pembelajaran, keterlibatan tutor sebaya dalam kelompok belajar membuat suasana pembelajaran lebih menarik, sedangkan faktor penghambatnya antara lain yaitu kurangnya persiapan dari para tutor, sarana dan prasarana kurang memadai, kegiatan pembelajaran kurang kondusif, dan sumber belajar kurang memadai.
\end{abstract}

\begin{abstract}
The objective of this study is to examine the implementation of peer tutoring learning model (peer teaching) in SMAN I Brebes. Subjects in this study were teachers sociology class XI IPS 1 and class XI IPS 1. Results show that the implementation of peer teaching requires preparation, and each stage of the implementation should be evaluated to obtain good results. Factors supporting the implementation of peer tutoring learning model, among others, the interaction between teachers and students, and also student interest is high; teachers and students are more familiar in learning activities, and peer tutor involvement in the study group to make the learning environment more attractive. The inhibiting factor of peer teaching strategy include among others the lack of preparation of the tutors, inadequate infrastructure, lack of conducive learning activities, and learning resources are inadequate.
\end{abstract}

(C) 2011 Universitas Negeri Semarang 


\section{PENDAHULUAN}

Model pembelajaran tutor sebaya merupakan (peer teaching) salah satu alternatif yang dapat diterapkan kepada siswa dalam proses belajar mengajar. Siswa cenderung merasa takut dan tidak berani untuk bertanya atau mengeluarkan pendapatnya kepada guru, tetapi siswa akan lebih suka dan berani bertanya atau mengeluarkan pendapatnya tentang materi pelajaran kepada temannya atau siswa lain. Sehingga dengan diterapkannya model pembelajaran tutor sebaya ini diharapkan dapat membantu siswa untuk dapat menerima materi pelajaran.

Model pembelajaran tutor sebaya yaitu pembelajaran yang dilakukan oleh teman-temannya yang mempunyai usia hampir sebaya (Djamarah, 1995:31). Kelebihan penggunaan model pembelajaran tutor sebaya antara lain adalah: 1) dapat melatih siswa atau dapat meningkatkan kemampuan untuk mengeluarkan pendapat dan berkomunikasi. Maksudnya pada keterampilan ini dasarnya berkenaan dengan kemampuan siswa menangkap pengertian atau makna dari apa yang didengar, dibaca, dan dilihat atau dilakukan kemudian menjelaskan penelitian atau makna hasil tangkapan dan hasil pengolahan pikiran dengan bahasa atau kata-kata sendiri sehingga dipahami oleh orang lain, 2) dapat melatih kemampuan siswa untuk berinisiatif dan kreativitas dalam kemampuan siswa mempunyai kesediaan atau kesiapan kemampuan dan keberanian untuk melakukan suatu hal baru atau hal lain dalam menangani suatu masalah, 3) untuk melatih kemampuan siswa untuk bekerja sama, maksudnya mempunyai semangat atau spirit dan kesediaan untuk berbuat bersama orang lain secara kompak dalam menangani suatu kegiatan yang secara sadar dirancang bersama guru untuk mendapatkan manfaat yang sebesar-besarnya, tetapi dalam proses pembelajaran guru juga mengawasi dan membantu tutor sebaya dalam pembelajaran di kelas.

Siswa dengan tingkat kepandaian yang tinggi dapat membantu siswa yang kurang pandai dengan mengajarkan materi atau melaksanakan bimbingan dalam menyelesaikan soal-soal atau permasalahan. Tutor sebaya dapat mengembangkan nilai-nilai kemanusiaan, siswa menjadi lebih percaya diri, saling membantu antar teman, menghargai pendapat orang lain dan mau menerima kekurangan diri sendiri sebagai sesuatu yang dapat dipenuhi dengan masukan dan bantuan orang lain.

Mengajar teman sebaya memberikan kesempatan kepada peserta didik untuk mempelajari sesuatu dengan baik pada waktu yang sama, ia menjadi narasumber bagi yang lain. Strategi tersebut merupakan cara praktis untuk mengajar teman sebaya di dalam kelas, dan juga memberikan tambahantambahan kepada pengajar apabila mengajar dilakukan oleh peserta didik (Silberman, 2001:74).

Mata pelajaran sosiologi merupakan salah satu dari sub kompetensi mata pelajaran Ilmu Pengetahuan Sosial yang diajarkan pada siswa kelas XI program IPS. Siswa akan belajar efektif jika mereka benar-benar tertarik terhadap pelajarannya. Akan tetapi, sulit bagi guru untuk menemukan persediaan ide tentang penyampaian pelajaran secara menarik. Model pembelajaran tutor sebaya dapat dijadikan salah satu model pembelajaran yang cukup bermanfaat serta berpengaruh dalam pemahaman konsep sosiologi bagi siswa.

Pertanyaan penelitian ini adalah bagaimana penerapan model pembelajaran tutor sebaya pada mata pelajaran Sosiologi di SMA Negeri 1 Tanjung Kabupaten Brebes. Bagaimana perencanaan dan pelaksanaan serta faktor pendukung dan penghambat dalam pelaksanaan model pembelajaran tersebut?

Tutor sebaya merupakan strategi pendekatan kooperatif yaitu model pembelajaran di mana siswa belajar dalam kelompok kecil yang dikelompokkan dengan tingkat kemampuan yang berbeda, semua anggota kelompok saling bekerja sama dan membantu untuk memahami bahan materi yang menciptakan saling menghargai sesama teman-teman lainnya. Secara umum kegiatan siswa yang belajar dalam kelompok kecil akan tumbuh dan berkembang dengan pola belajar tutor sebaya (peer group) dan belajar secara bekerja sama (cooperative). 
Ketika proses belajar dengan tutor sebaya berlangsung, terjadi pendekatan kooperatif karena tutor sebaya akan menggunakan bahasa sehari-hari dan bisa lebih akrab, sehingga pembelajar atau siswa yang dibantu oleh tutor sebaya bisa mengembangkan kemampuan dengan lebih baik untuk memahami materi. Manfaat pembelajaran dengan tutor sebaya dapat menjadikan siswa lebih senang belajar, kreatif, dan menyenangkan dalam kegiatannya karena siswa lebih mudah bertanya, lebih terbuka dengan teman sebaya daripada dengan gurunya.

Sekolah memiliki banyak potensi yang dapat ditingkatkan efektivitasnya untuk menunjang keberhasilan suatu program pengajaran. Potensi yang ada di sekolah, yaitu semua sumber daya yang dapat mempengaruhi hasil dari proses belajar mengajar. Keberhasilan suatu program pengajaran tidak disebabkan oleh satu macam sumber daya, tetapi disebabkan oleh perpaduan antara berbagai sumber-sumber daya yang saling mendukung menjadi satu sistem yang integral (Cece Wijaya, dkk, 1988 dalam Suherman, 2003:276).

Menurut Harsunarko (dalam Suherman, 2003:276) dalam arti luas sumber belajar tidak harus selalu guru. Sumber belajar dapat orang lain yang bukan guru, melainkan teman dari kelas yang lebih tinggi, teman sekelas, atau keluarganya di rumah. Sumber belajar bukan guru dan berasal dari orang yang lebih pandai disebut tutor. Ada dua macam tutor, yaitu tutor sebaya dan tutor kakak. Tutor sebaya adalah teman sebaya yang lebih pandai, sedangkan tutor kakak adalah tutor dari kelas yang lebih tinggi.

Suherman (2003:276) mengemukakan bahwa tutor sebaya adalah sekelompok siswa yang telah tuntas terhadap bahan pelajaran, memberikan bantuan kepada siswa yang mengalami kesulitan dalam memahami bahan pelajaran yang dipelajarinya. Sedangkan Conny Semiawan (dalam Suherman, 2003:276) mengemukakan tentang tutor sebaya itu adalah siswa yang pandai dapat memberikan bantuan belajar kepada siswa yang kurang pandai. Bantuan tersebut dapat dilakukan kepada teman-teman sekelasnya di luar sekolah. Mengingat bahwa siswa ada- lah unsur pokok dalam pengajaran, maka siswalah yang harus menerima dan mencapai berbagai informasi pengajaran yang pada akhirnya dapat mengubah tingkah lakunya sesuai yang diharapkan. Untuk itu, maka siswa harus dijadikan sebagai sumber pertimbangan didalam pemilihan sumber pengajaran.

Dinkmeyer (dalam Suherman, 2003: 276) mengatakan bahwa tugas sebagai tutor merupakan kegiatan yang kaya akan pengalaman yang justru sebenarnya merupakan kebutuhan anak itu sendiri. Dalam persiapan ini antara lain mereka berusaha mendapatkan hubungan dan pergaulan baru yang mantap dengan teman sebaya, mencari perannya sendiri, mengembangkan kecakapan intelektual dan konsep-konsep yang penting, mendapatkan tingkah laku yang bertanggung jawab secara sosial. Dengan demikian beban yang diberikan kepada mereka akan memberi kesempatan untuk mendapatkan perannya, bergaul dengan orang lain, dan bahkan mendapatkan pengetahuan dan pengalaman.

Muntasir mengemukakan bahwa tutor berfungsi sebagai tukang atau pelaksana mengajar, cara mengajarnya telah disiapkan secara khusus dan terperinci. Fungsi lainnya adalah dengan adanya tutor sebaya, siswa yang kurang aktif dapat menjadi lebih aktif karena tidak malu lagi untuk bertanya dan mengeluarkan pendapat secara bebas, sebagaimana diungkapkan oleh M. Saleh Muntasir bahwa dengan pergaulan antara para tutor dengan murid-muridnya mereka dapat mewujudkan apa yang terpendam dalam hatinya dan khayalannya. Jadi, pembelajaran dengan tutor sebaya akan membantu siswa yang kurang mampu atau kurang cepat menerima pelajaran dari gurunya. Kegiatan tutor sebaya bagi siswa merupakan kegiatan yang kaya akan pengalaman yang sebenarnya merupakan kebutuhan siswa itu sendiri. Tutor maupun yang ditutori sama-sama diuntungkan, bagi tutor akan mendapat pengalaman, sedangkan yang ditutori akan lebih kreatif dalam menerima pelajaran.

Menurut Longstreth (dalam Suherman, 2003:233) siswa yang kurang mampu dalam memahami materi bisa langsung ber- 
tanya dan minta bimbingan pada temannya sendiri tanpa adanya perasaan canggung, takut, atau malu sehingga akan lebih memudahkan siswa untuk menguasai konsep yang ada di dalam materi pelajaran.

Tutor sebaya adalah sumber belajar selain guru, yaitu teman sebaya yang lebih pandai memberikan bantuan belajar kepada teman-teman sekelasnya di sekolah. Bantuan belajar oleh teman sebaya dapat menghilangkan kecanggungan, bahasa teman sebaya lebih mudah dipahami. Dengan teman sebaya tidak ada rasa enggan, rendah diri, malu, dan sebagainya untuk bertanya ataupun minta bantuan.

Berdasarkan pendapat tokoh-tokoh tersebut di atas, peneliti berpendapat bahwa model pembelajaran Tutor Sebaya diharapkan cocok dilaksanakan untuk mempelajari mata pelajaran sosiologi pada siswa kelas XI IPS 1 di SMA Negeri 1 Tanjung Kabupaten Brebes yang mempunyai berbagai tingkat kepandaian, tetapi berada dalam kelas kecil. Siswa dengan tingkat kepandaian yang tinggi dapat membantu siswa yang kurang pandai, dengan mengajarkan materi atau melaksanakan bimbingan dalam menyelesaikan soal-soal atau permasalahan. Tutor sebaya dapat mengembangkan nilai-nilai kemanusiaan, siswa menjadi lebih percaya diri, saling membantu antar teman, menghargai pendapat orang lain dan mau menerima kekurangan diri sendiri sebagai sesuatu yang dapat dipenuhi dengan masukan dan bantuan dari orang lain.

Dalam pembelajaran tutor sebaya, teman sebaya yang lebih pandai memberikan bantuan belajar kepada teman sekelasnya di sekolah. Bantuan belajar oleh teman sebaya dapat menghilangkan kecanggungan sehingga teman yang diajar tidak malu untuk mengungkapkan kesulitan-kesulitan yang dihadapinya. Untuk menentukan tutor, guru dapat melihat dari perkembangan akademik siswa seperti peringkat yang tinggi di kelasnya.

Inti dari pembelajaran tutor sebaya adalah pembelajaran yang pelaksanaannya dengan membagi kelas ke dalam kelompokkelompok kecil, yang sumber belajarnya bukan hanya guru tetapi juga teman sebaya yang pandai dan cepat dalam menguasai suatu materi. Dalam pembelajaran disini siswa yang menjadi tutor hendaknya mempunyai kemampuan akademik yang lebih tinggi dibandingkan dengan teman lainnya, sehingga pada saat dia memberikan bimbingan dia sudah menguasai bahan yang akan disampaikan (Huda, 2009:28).

Tujuan pembelajaran dari model tutor sebaya ini adalah memberikan kesempatan kepada siswa untuk mengembangkan kemampuan dalam memecahkan masalah secara rasional, mengembangkan sifat sosial dan semangat gotong royong dalam kehidupan, mendominasikan kegiatan kelompok dalam belajar dan setiap anggota merasa sadar diri sebagai kelompok yang bertanggung jawab, mengembangkan kemampuan kepemimpinan, keterampilan pada tiap anggota kelompok dalam memecahkan masalah kelompok.

Seorang tutor hendaknya memiliki kriteria sebagai berikut: 1) memiliki kemampuan akademis di atas rata-rata siswa satu kelas, 2) mampu menjalin kerja sama dengan sesama siswa, (3) memiliki motivasi tinggi untuk meraih prestasi akademis yang baik, (4) memiliki sikap toleransi dan tenggang rasa dengan sesama, (5) memiliki motivasi tinggi untuk menjadikan kelompok diskusinya sebagai yang terbaik, (6) bersikap rendah hati, pemberani, dan bertanggung jawab, dan (7) suka membantu sesamanya yang mengalami kesulitan.Tutor atau ketua kelompok memiliki tugas dan tanggung jawab sebagai berikut: (1) memberikan tutorial kepada anggota terhadap materi ajar yang sedang dipelajari, (2) mengkoordinir proses diskusi agar berlangsung kreatif dan dinamis, (3) menyampaikan permasalahan kepada guru pembimbing apabila ada materi ajar yang belum dikuasai.

Penelitian Lathifah Annuur (2009), Huda (2009) dan Rachmiati ( 2010) menyimpulkan bahwa terdapat peningkatan kualitas pembelajaran melalui penerapan model pembelajaran tutor sebaya dalam kelompok Kecil. Hal tersebut terefleksi dari beberapa indikator sebagai berikut: 1) siswa antusias dan bersemangat dalam mengikuti pembelajaran, 2) siswa mampu mengatasi kesulitan 
belajar dengan berdiskusi bersama teman yang telah ditunjuk sebagai tutor pada tiap kelompok, 3) siswa mampu mempresentasikan hasil kerja kelompoknya ke depan kelas, 4) guru mampu memberikan metode pembelajaran dengan nuansa yang baru. Dengan demikian dapat disimpulkan bahwa dengan penerapan model pembelajaran tutor sebaya dalam Kelompok Kecil dapat meningkatkan kualitas proses dan hasil belajar siswa, baik dari segi keaktifan maupun hasil belajar.

\section{METODE PENELITIAN}

Penelitian ini dilaksanakan di SMA Negeri 1 Tanjung, Kabupaten Brebes. Alasan peneliti memilih tempat tersebut dikarenakan peneliti ingin mengetahui bagaimana model tutor sebaya diterapkan oleh guru sosiologi SMA Negeri 1 Tanjung, Kabupaten Brebes dalam proses pembelajaran. Selain itu, peneliti juga melihat dalam kegiatan pembelajarannya masih monoton, guru masih bergantung pada buku paket sebagai sumber materi pelajaran.

Data primer dalam penelitian ini adalah data-data yang diperoleh secara langsung dari subjek penelitian, yaitu dari guru sosiologi kelas XI IPS 1 dan siswa kelas XI IPS 1 SMA Negeri 1 Tanjung, baik yang bertugas menjadi tutor sebaya maupun yang tidak.

Dalam penelitian ini peneliti menggunakan model student to tutor, adapun langkah model ini adalah sebagai berikut: Pilihlah siswa yang memiliki kemampuan diatas rata-rata. Berikan tugas khusus untuk membantu temannya dalam bidang tertentu. Guru selalu memantau proses saling membantu tersebut. Dan terakhir berikan penguatan kepada kedua belah pihak agar baik anak yang membantu maupun yang dibantu merasa senang (Winataputra, 2000:38).

Selain memperoleh data dengan observasi di dalam kelas, hasil penelitian juga diperoleh dari wawancara dengan guru sosiologi dan siswa khususnya kelas XI IPS 1.

Kelas XI IPS di SMA Negeri 1 Tanjung terdiri dari 5 kelas, tetapi hanya diambil satu kelas saja yaitu kelas XI IPS 1 untuk penelitian. Hal ini dikarenakan kelas XI IPS 1 mempunyai rata-rata nilai yang rendah dibandingkan dengan kelas yang lainnya, selain itu juga karena kelas XI IPS 1 dalam kegiatan pembelajaran suasananya kurang hidup.

Dalam penelitian ini mengambil materi Konflik dan Integrasi Sosial, yang bertujuan untuk mengetahui bagaimana aktivitas siswa dalam kegiatan pembelajaran serta hasil belajar sosiologi dengan menggunakan model pembelajaran tutor sebaya di SMA Negeri 1 Tanjung. Pembelajaran dilakukan pada bulan September sampai dengan bulan Oktober 2010 dan dilaksanakan setiap hari rabu pada jam kelima sampai dengan ketujuh (pukul 10.15 sampai dengan pukul

Tabel 1. Identitas subjek penelitian

\begin{tabular}{lll}
\hline \multicolumn{1}{c}{ Nama } & Umur & \multicolumn{1}{c}{ Keterangan } \\
\hline Sumarni, S.Pd & 48 tahun & Guru Sosiologi \\
Intan Sueno & 16 tahun & Siswi kelas XI IPS 1 \\
Ika Nur Utami & 15 tahun & Siswi kelas XI IPS 1 \\
M. Hanif Ibnusholih & 16 tahun & Siswa kelas XI IPS 1 \\
Singgih Fajar Nugraha & 16 tahun & Siswa kelas XI IPS 1 \\
Ken Mardlotila & 16 tahun & Siswi kelas XI IPS 1 \\
Titin Agustin & 15 tahun & Siswi kelas XI IPS 1 \\
Moh. Agung Saefunnuha & 16 tahun & Siswa kelas XI IPS 1 \\
Iqbal Alfando & 16 tahun & Siswa kelas XI IPS 1 \\
Wiwin Windahsari & 16 tahun & Siswi kelas XI IPS 1 \\
Rizki Ade Putri & 16 tahun & Siswi kelas XI IPS 1 \\
\hline
\end{tabular}


Tabel 2. Jadwal Pelaksanaan Penelitian

\begin{tabular}{ccl}
\hline Pertemuan & Tanggal & \multicolumn{1}{c}{ Materi Pelajaran } \\
\hline I & 14 September 2010 & Hakikat Konflik Sosial \\
II & 21 September 2010 & Konflik dan Kekerasan \\
III & 28 September 2010 & Sebab dan Dampak Konflik \\
IV & 5 Okober 2010 & Integrasi Sosial \\
V & 12 Oktober 2010 & Faktor-faktor Integrasi Sosial \\
VI & 19 Oktober 2010 & Ulangan harian \\
\hline
\end{tabular}

12.45 WIB). Penelitian dilaksanakan dalam $6 \mathrm{x}$ pertemuan atau 6 minggu, di mana $5 x$ pertemuan untuk kegiatan pembelajaran dan $1 \mathrm{x}$ pertemuan untuk evaluasi yang berupa ulangan harian. Adapun jadwal pelaksanaan penelitian sebagai berikut:

Dalam tahap perencanaan ini berupa rencana kegiatan yaitu menentukan langkah-langkah yang dilakukan peneliti untuk memecahkan masalah yang akan dikaji. Langkah ini merupakan langkah awal dalam pelaksanaan pembelajaran dengan menggunakan model pembelajaran tutor sebaya yang telah dipersiapkan. Rencana kegiatan yang akan dilaksanakan antara lain sebagai berikut: a) menyusun program pembelajaran dengan model tutor sebaya, b) menyusun rencana pelaksanaan pembelajaran yang dilakukan oleh peneliti bersama dengan guru mata pelajaran sosiologi, c) menyiapkan pedoman observasi yang terdiri dari lembar aktivitas siswa, lembar observasi kinerja guru, dan pedoman wawancara.

\section{HASIL DAN PEMBAHASAN}

SMA Negeri 1 Tanjung terletak di Jalan Cemara Tanjung Kabupaten Brebes, Provinsi Jawa Tengah, tepatnya di Desa Lemahabang. SMA Negeri 1 Tanjung ini berada di pinggir jalan utama penghubung Kecamatan Tanjung dan Kecamatan Kersana, Kabupaten Brebes sehingga memudahkan siswa yang pulang pergi ke sekolah karena jalan ini sering dilalui angkutan umum. SMA Negeri 1 Tanjung mempunyai visi, misi, dan tujuan sekolah sebagai berikut: Terwujudnya Generasi Muda Yang Bermutu dan Dibutuhkan
Masyarakat

Ketenagaan di SMA Negeri 1 Tanjung terdiri dari 1 kepala sekolah, 20 tenaga administrasi, dan 52 guru yang terdiri dari 37 guru tetap dan 15 guru tidak tetap.

Untuk guru yang mengajar mata pelajaran sosiologi ada 4 guru, di mana 2 guru untuk kelas X, 1 guru untuk kelas XI IPS, dan 1 guru untuk kelas XII IPS. Masing-masing guru tersebut bukan berasal dari lulusan sarjana sosiologi. Untuk guru sosiologi kelas X yaitu Ibu Mourint Titus Miftita, S.Pd adalah sarjana ekonomi, sedangkan guru sosiologi kelas XI IPS yaitu Ibu Sumarni, S.Pd adalah sarjana pendidikan kewarganegaraan, sedangkan guru sosiologi kelas XII IPS yaitu Ibu Yuni Praptiningsih, S.Sos adalah sarjana ilmu sosiologi.

\section{Perencanaan Model Pembelajaran}

Persiapan atau perencanaan merupakan faktor yang sangat mendukung dan memegang peranan yang sangat penting untuk dapat melaksanakan suatu pembelajaran yang baik dan untuk menciptakan sebuah kondisi yang kondusif dalam kegiatan belajar mengajar sehingga dapat mendorong peserta didik untuk dapat lebih mudah menguasai sejumlah kompetensi sebagaimana yang termuat dalam kurikulum. Berkenaan dengan hal tersebut, maka guru SMA Negeri 1 Tanjung termasuk guru sosiologi dituntut untuk dapat mempersiapkan sebaik mungkin segala sesuatu yang sekiranya perlu dalam sebuah kegiatan belajar mengajar.

Berdasarkan hasil observasi di SMA Negeri 1 Tanjung, guru lebih sering menggunakan model pembelajaran konvensional 
dalam kegiatan belajar mengajar sehingga banyak siswa yang tidak aktif dan sering kali siswa terlihat mengacuhkan penjelasan guru, mereka terlihat asyik dengan kesibukannya masing-masing sehingga kurang memperhatikan materi yang disampaikan oleh guru. Apalagi untuk kelas XI IPS 1 ini mata pelajaran sosiologi berlangsung cukup lama yaitu selama 3 jam pelajaran sekaligus, sehingga guru harus bisa menentukan metode atau model pembelajaran yang lainnya agar kegiatan belajar mengajar tidak membosankan.

Berkaitan dengan hal tersebut, penggunaan model pembelajaran tutor sebaya diharapkan dapat membantu siswa dalam penerimaan materi pelajaran. Model pembelajaran ini dapat juga membantu guru untuk meningkatkan keaktifan siswa di dalam kegiatan pembelajaran karena dengan model ini siswa dituntut untuk lebih aktif dalam kegiatan pembelajaran, dan dapat memotivasi siswa terutama dalam kegiatan pembelajaran sosiologi. Sebelum melaksanakan kegiatan belajar mengajar guru di SMA Negeri 1 Tanjung pada umumnya dan guru mata pelajaran sosiologi khususnya terlebih dahulu membuat perangkat pembelajaran yang meliputi program tahunan, program semester, perhitungan minggu efektif, silabus, dan rencana pelaksanaan pembelajaran (RPP). Pembuatan perangkat pembelajaran dilakukan sebagai langkah awal guru agar kegiatan belajar mengajar dapat berjalan dengan lancar dan sesuai dengan apa yang diinginkan.

Dalam pembuatan perangkat pembelajaran guru perlu menyesuaikan dan memperhitungkan alokasi waktu untuk kegiatan pembelajaran yang efektif agar semua kompetensi pada mata pelajaran sosiologi dalam satu semester dapat dicapai oleh siswa.

Menurut Akrom (dalam Rachmiati, 2010:19) perencanaan pembelajaran menggunakan model tutor sebaya adalah sebagai berikut:

Guru membuat program pengajaran satu pokok bahasan yang dirancang dalam bentuk penggalan-penggalan materi pokok pembelajaran pada setiap pertemuan. Program ini berisi materi-materi pokok yang akan disampaikan oleh guru pada tiap-tiap pertemuan, selain itu juga mencakup renca- na kegiatan yang akan dilakukan pada kegiatan pembelajaran.

Menentukan beberapa orang siswa yang memenuhi kriteria sebagai tutor sebaya. Jumlah tutor sebaya yang di tunjuk disesuaikan dengan jumlah kelompok yang dibentuk. Dalam menentukan tutor dengan memperhatikan atau memilih siswa yang mempunyai kemampuan akademik yang tinggi, seperti siswa dengan peringkat satu sampai dengan sepuluh.

Berdasarkan hasil penelitian guru telah menunjuk tujuh orang siswa untuk dijadikan sebagai tutor. Mereka antara lain adalah Ahmad Bashir, Fathikah, Intan Sueno, M. Hanif Ibnusholih, Moh. Agung Saefunnuha, Singgih Fajar Nugroho, dan Wiwin Windahsari.

Guru memberikan tugas kepada para tutor terlebih dahulu sebelum tutor-tutor tersebut memberikan bimbingan kepada teman-temannya.

Para tutor diberikan beberapa tugas oleh guru setelah jam pelajaran selesai, tugas tersebut berupa pertanyaan-pertanyaan atau permasalahan yang mencakup materi pelajaran untuk pertemuan-pertemuan selanjutnya. Hal ini dilakukan supaya para tutor lebih siap dalam membimbing teman-temannya pada saat kegiatan pembelajaran di kelas. Selain dengan pemberian tugas yang dilakukan oleh guru, siswa juga diberikan materi tambahan yang diambil dari berbagai sumber, baik dari buku paket yang lainnya maupun dari internet.

\section{Pelaksanaan Model Pembelajaran}

Berdasarkan hasil pengamatan kelas yang penulis dapat diuraikan bahwa suasana kelas pada saat kegiatan pembelajaran sosiologi berlangsung cukup baik. Meskipun dalam penyampaian materi pelajaran guru jarang menggunakan model pembelajaran, namun guru sosiologi di SMA Negeri 1 Tanjung tetap berusaha menciptakan suasana belajar yang efektif dan kondusif. Misalnya guru memberikan tugas kelompok untuk mendiskusikan dan mencari jalan keluar suatu permasalahan yang ada di masyarakat, kemudian dipresentasikan di depan kelas. 


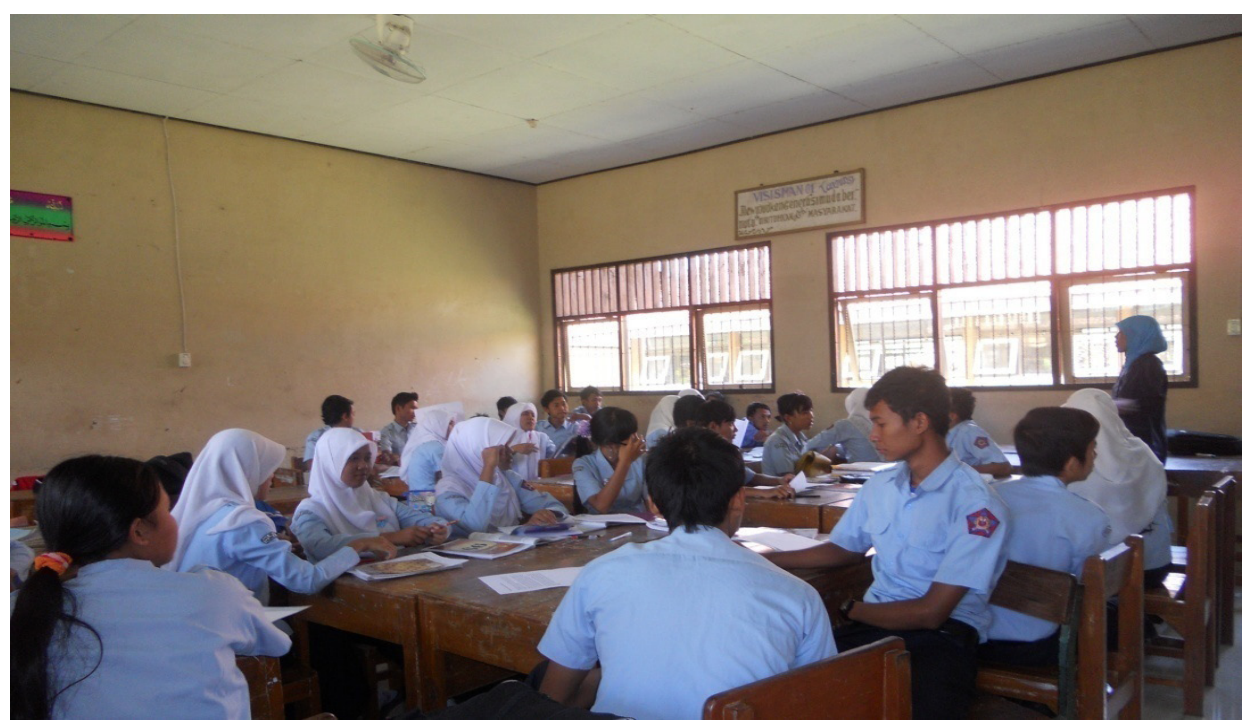

Gambar 1. Guru sedang memberikan penjelasan tentang model pembelajaran Tutor Sebaya di kelas XI IPS 1 (Dokumen Ningrum tanggal 14 September 2010).

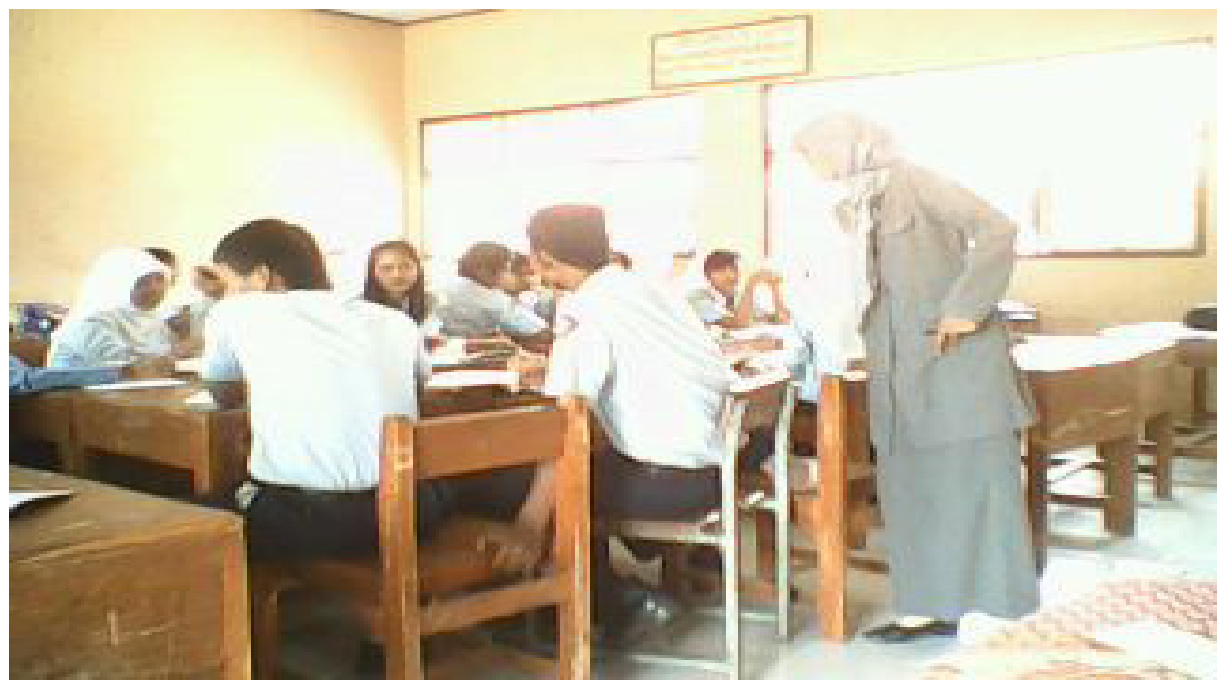

Gambar 2. Guru sedang memantau kegiatan diskusi (Dokumen Ningrum tanggal 14 September 2010).

Hal tersebut tentunya memberikan efek yang positif terhadap siswa, karena siswa secara langsung dapat membangun pengetahuan yang sudah ada pada diri siswa itu sendiri, membangun daya kritis dan kreativitas siswa, serta dapat menjadi bekal yang cukup dalam hidup bermasyarakat baik sekarang maupun yang akan datang.

Proses pembelajaran menggunakan model pembelajaran tutor sebaya ini meliputi beberapa langkah, antara lain: langkah pertama dalam kegiatan pembelajaran di kelas guru mengkondisikan siswa dan memberitahukan kepada siswa bahwa untuk pembelajaran kali ini akan menggunakan model pembelajaran tutor sebaya. Kemudian guru menjelaskan langkah-langkah pembelajaran dengan model tutor sebaya ini kepada siswa. Setelah itu guru mulai menyampaikan materi-materi yang akan dipelajari pada pertemuan tersebut.

Pada pertemuan pertama dalam kegiatan pembelajaran dengan model pembelajaran tutor sebaya, guru mempersiapkan kelas untuk kegiatan pembelajaran yaitu dengan mengucapkan salam, mengabsen siswa, dan menyampaikan tujuan pembelajaran yang ingin dicapai. Kemudian guru memberikan apersepsi kepada siswa dengan cara mengajukan beberapa pertanyaan mengenai materi 
yang akan dipelajari yaitu tentang konflik sosial, selain itu untuk memancing motivasi siswa guru menginformasikan bahwa akan memberi penghargaan kepada siswa yang aktif dalam kegiatan pembelajaran.

Dalam kegiatan inti ini pembelajaran dibagi menjadi tiga kegiatan yaitu eksplorasi, elaborasi, dan konfirmasi. Untuk kegiatan eksplorasi guru mengajak siswa untuk mendefinisikan pengertian konflik dan mendeskripsikan contoh-contoh konflik yang ada di masyarakat. Berdasarkan hasil pengamatan peneliti siswa masih belum sepenuhnya memperhatikan penjelasan guru karena masih ada siswa yang terlalu sibuk dengan kegiatannya masing-masing, saat guru memberikan pertanyaan hanya beberapa siswa saja yang menjawabnya. Kemudian untuk kegiatan elaborasinya yaitu guru mulai menyampaikan materi pelajaran hari itu kepada siswa yaitu tentang pengertian konflik sosial dan contoh berbagai konflik yang ada atau pernah terjadi di masyarakat.

Setelah menyampaikan materi guru mulai menerapkan model pembelajaran tutor sebaya, kelas dibagi menjadi tujuh kelompok dengan masing-masing kelompok terdapat satu orang tutor. Kemudian guru memberikan soal untuk didiskusikan dengan bantuan tutor sebaya, sebelum mulai berdiskusi tutor memberikan kesempatan kepada anggota kelompoknya untuk bertanya mengenai materi pelajaran yang telah disampaikan oleh guru. Guru selalu memantau kegiatan tutoring dan diskusi dengan cara mengelilingi setiap kelompok yang sedang berdiskusi, barangkali ada kelompok yang mengalami kesulitan dalam diskusi, atau tutor yang mengalami kesulitan dalam menjawab pertanyaan dari anggota kelompoknya.

Setelah kegiatan diskusi selesai, guru menyuruh perwakilan dari masing-masing kelompok maju untuk mempresentasikan hasil diskusinya. Kegiatan presentasi berjalan cukup lancar, tetapi ada beberapa kelompok yang masih terlihat malu-malu dalam mempresentasikan hasil diskusi kelompoknya sehingga dalam penyampaian hasil diskusinya belum jelas dan tidak tegas. Hal tersebut dapat dimaklumi karena guru jarang mengadakan kegiatan diskusi dan presentasi di depan kelas.

Sedangkan untuk kegiatan konfirmasi, guru melakukan tanya jawab mengenai apa yang telah dipelajari pada hari tersebut sebagai umpan balik, setelah itu guru menyuruh siswa untuk menyimpulkan hasil diskusi. Untuk kegiatan penutup guru bersama dengan siswa menyimpulkan materi yang telah dipelajari hari ini, dan sebelum menutup pelajaran guru memberi kesempatan bertanya kepada siswa.

Pada pertemuan kedua untuk kegiatan pendahuluan seperti biasanya guru terlebih dahulu memberikan apersepsi dan motivasi kepada siswa. Kemudian guru mengulas materi yang telah diberikan pada pertemuan sebelumnya untuk mengetahui sejauh mana ingatan siswa tentang materi yang telah disampaikan. Pada pertemuan kedua ini guru akan menyampaikan materi tentang konflik dan kekerasan, dengan indikator siswa diharapkan dapat membedakan konflik dengan kekerasan. Saat kegiatan pembelajaran siswa terlihat lebih aktif, ada beberapa siswa yang mencatat inti dari penjelasan guru, dan beberapa siswa mulai ada yang mengajukan pertanyaan. Sehingga kegiatan pembelajaran bersifat dua arah, guru memberikan materi kepada siswa dan siswa dapat menyampaikan pendapat-pendapatnya.

Setelah penyampaian materi, kemudian guru menyuruh siswa untuk duduk sesuai dengan kelompoknya masing-masing yang telah ditentukan pada pertemuan sebelumnya, para tutor yang telah dipilih disebar ke kelompok-kelompoknya. Guru membagikan artikel tentang konflik dan kekerasan kepada tiap-tiap kelompok, kemudian menyuruh siswa untuk menganalisis artikel tersebut dengan bantuan tutor sebaya, adapun halhal yang harus dianalisis antara lain yaitu pelaku konflik atau kekerasan, penyebab konflik atau kekerasan itu terjadi, teori kekerasan, cara untuk mengendalikan konflik/ kekerasan, dan dampak yang ditimbulkan dari kasus tersebut.

Para tutor memimpin jalannya diskusi pada tiap-tiap kelompoknya agar semua anggota dapat berlibat aktif dalam kegiatan diskusi. Tutor membimbing anggota kelompoknya agar dapat menganalisis artikel terse- 


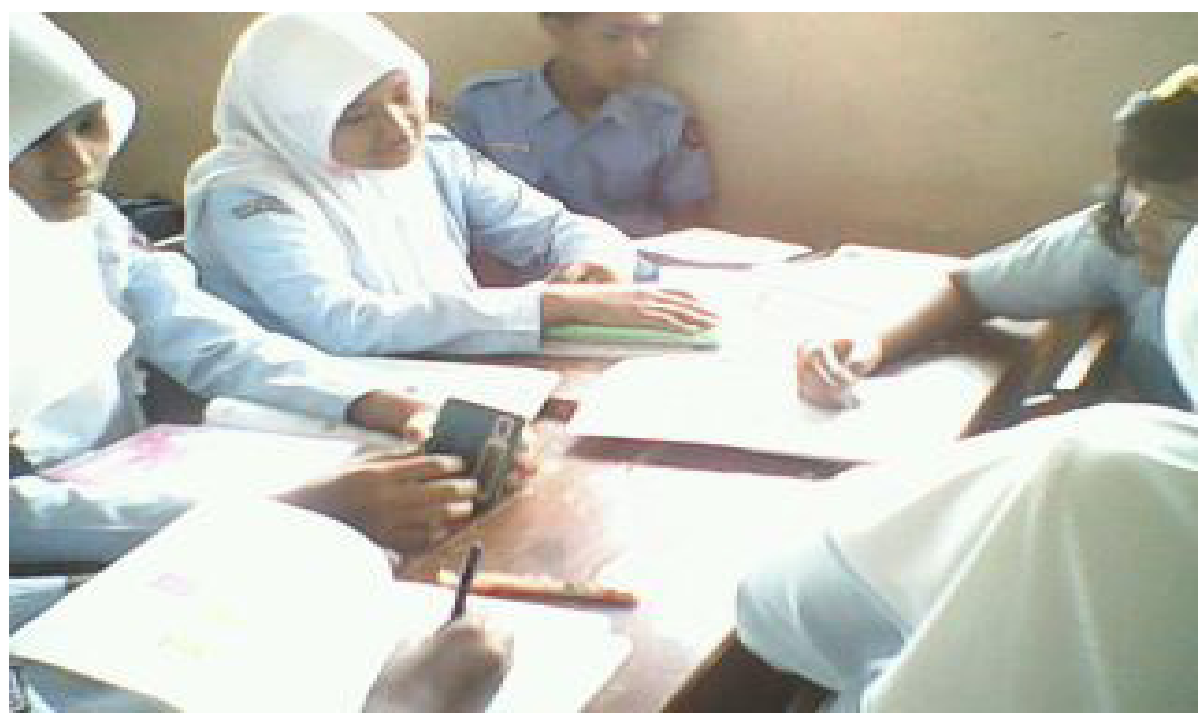

Gambar 3. Tutor sedang membimbing anggota kelompoknya dalam kegiatan diskusi (tutor yang tidak memakai jilbab) (Dokumen Ningrum tanggal 21 September 2010).

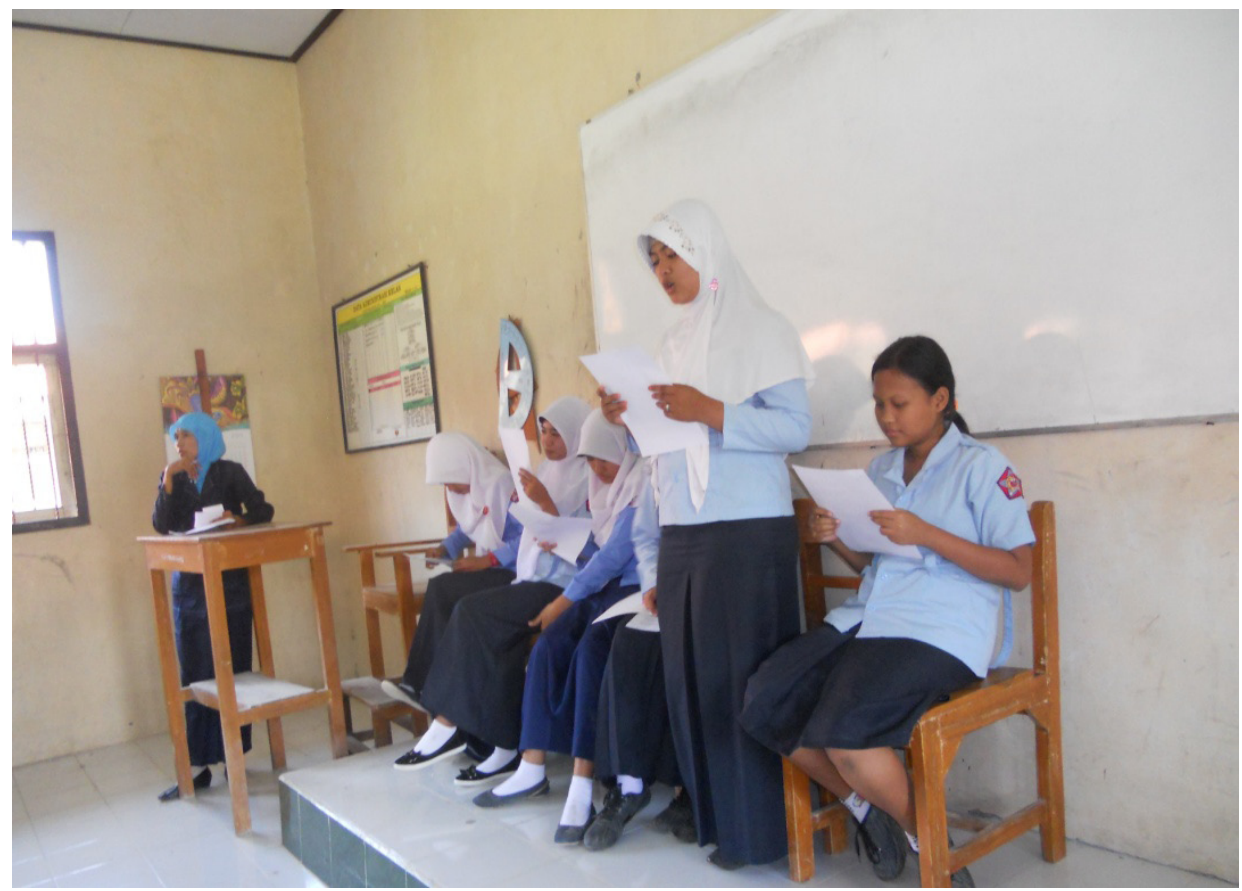

Gambar 4. Siswa sedang mempresentasikan hasil diskusi kelompoknya (Dokumen Ningrum tanggal 28 September 2010).

but dengan baik dan benar, pada saat diskusi guru memantau siswa dengan cara berjalan mendekati tiap-tiap kelompok dan menanyakan apakah ada kesulitan dalam menganalisis artikel tersebut.

Setelah kegiatan diskusi selesai guru menyuruh perwakilan dari masing-masing kelompok untuk maju mempresentasikan hasil diskusinya. Setelah semua perwakilan masing-masing kelompok mempresenta- sikan hasil diskusi kelompoknya, sebelum mengakhiri pertemuan hari tersebut guru memberikan tugas rumah kepada siswa yaitu mencari salah satu artikel mengenai kasus kekerasan di koran, kemudian dianalisis. Adapun hal-hal yang harus dianalisis antara lain adalah pelaku konflik/kekerasan, penyebab kekerasan, teori kekerasan, cara pengendalian kekerasan, dan dampak yang ditimbulkan dengan adanya kekerasan ter- 


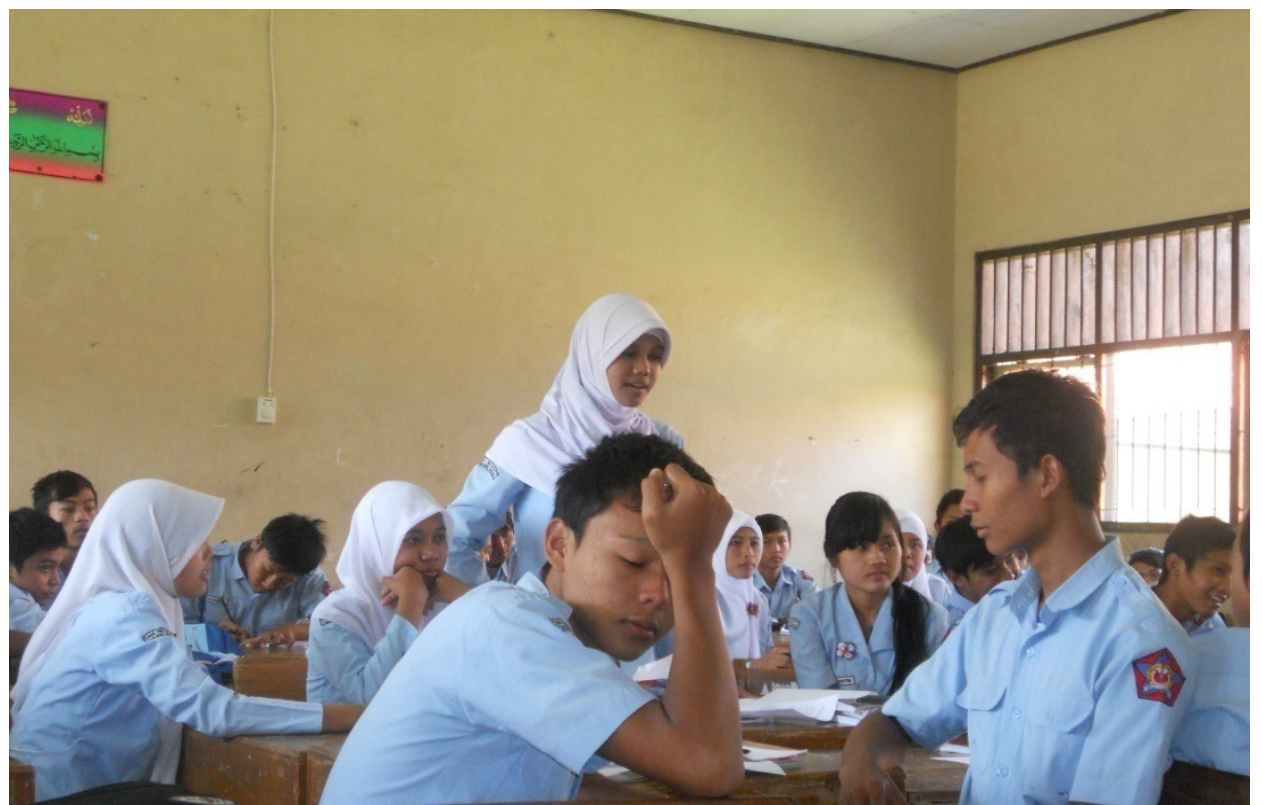

Gambar 5. Siswa sedang mengemukakan pendapatnya (Dokumen Ningrum tanggal 28 September 2010).

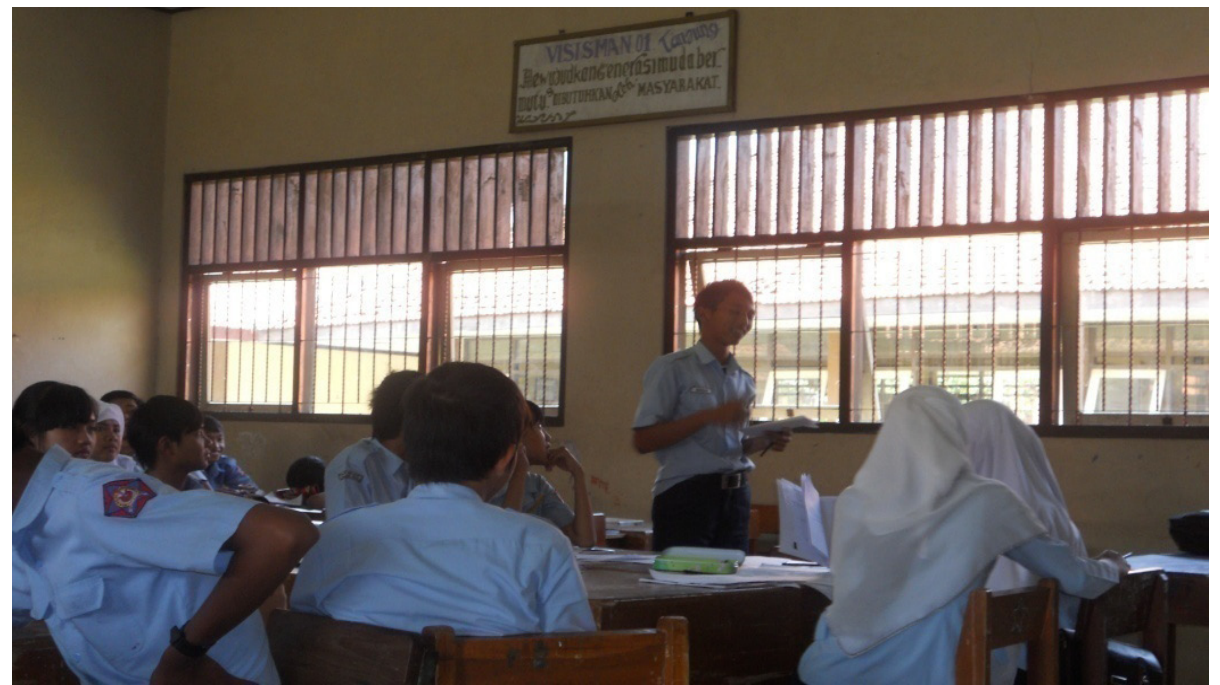

Gambar 6. Siswa sedang bertanya saat presentasi hasil diskusi (Dokumen Ningrum tanggal 5 Oktober 2010).

sebut. Setelah memberikan tugas kemudian guru mengakhiri pertemuan hari tersebut dengan mengucapkan salam dan meninggalkan ruangan kelas XI IPS 1.

Pada pertemuan ketiga, guru menyuruh siswa mengumpulkan tugas rumahnya, kemudian ada beberapa siswa yang ditunjuk untuk maju mempresentasikan tugasnya. Kemudian guru melanjutkan menyampaikan materi tentang sebab-sebab dan dampak terjadinya konflik di masyarakat, siswa memperhatikan penjelasan guru dengan seksama. Setelah itu guru menyuruh siswa untuk duduk sesuai dengan kelompoknya masing-masing dan membagikan gambar tentang konflik kepada setiap kelompok, siswa disuruh untuk mendiskusikan dan menganalisis gambar tersebut.

Saat kegiatan diskusi berlangsung semua kelompok terlihat aktif berdiskusi dengan anggota kelompoknya, guru seperti pada pertemuan-pertemuan sebelumnya berkeliling kelas, memantau berlangsungnya kegiatan diskusi, dan memberikan bimbingan 


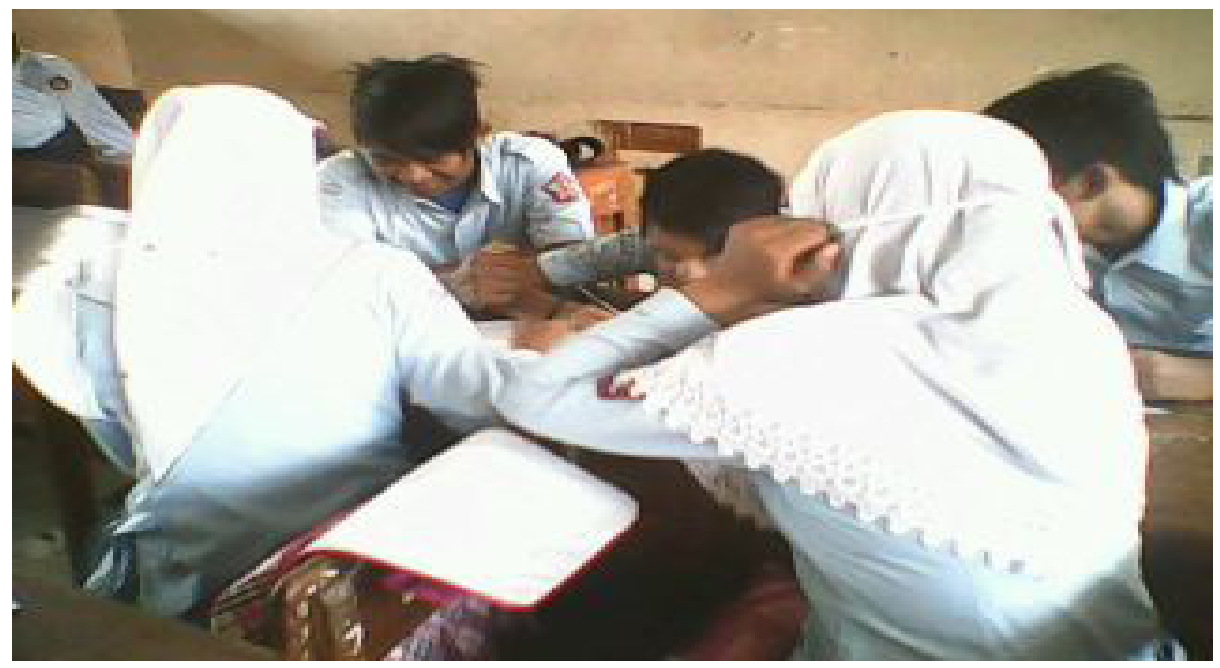

Gambar 7. Siswa sedang berdiskusi dengan kelompoknya (Dokumen Ningrum tanggal 12 Oktober 2010).

pada kelompok yang mengalami kesulitan. Setelah berdiskusi kemudian guru menyuruh perwakilan dari masing-masing kelompok untuk mempresentasikan hasil diskusinya.

Aktivitas yang terlihat sebelum menggunakan model pembelajaran tutor sebaya adalah siswa hanya mendengarkan penjelasan dari guru. Setelah model pembelajaran tutor sebaya diterapkan, aktivitas siswa mengalami peningkatan, diantaranya adalah siswa telah mampu melibatkan diri dalam kegiatan pembelajaran seperti memberikan argumen, pertanyaan, serta menjawab pertanyaan yang diajukan oleh guru. Dari observasi aktivitas siswa selama kegiatan pembelajaran, ada peningkatan aktivitas belajar siswa, akan tetapi masih perlu ditingkatkan lagi pada pertemuan selanjutnya. Hal ini dikarenakan beberapa siswa masih terlihat malu dan takut untuk mengajukan pertanyaan, walaupun yang memberikan materi adalah temannya sendiri. Guru harus lebih baik dalam mengelola kelas sehingga siswa merasa senang melakukan kegiatan belajarnya, bertanggung jawab terhadap tugasnya, serta terus mengupayakan untuk memotivasi siswa yang tidak aktif agar dapat terlibat secara aktif dalam kegiatan diskusi.

Pada pertemuan keempat, dimulai dengan penyampaian materi oleh guru dengan diselingi tanya jawab, guru menyampaikan materi tentang integrasi sosial. Setelah guru menjelaskan materi, guru memberikan kesempatan kepada siswa untuk bertanya tentang hal-hal yang tidak dipahami terkait dengan materi. Guru memberikan penjelasan atas pertanyaan yang diajukan oleh siswa. Setelah menyampaikan materi kemudian dilanjutkan dengan diskusi kelompok, pada pelaksanaan diskusi kelompok masih sama seperti pada pertemuan-pertemuan sebelumnya dengan anggota kelompok yang masih sama.

Setelah kegiatan diskusi selesai, dilanjutkan dengan presentasi hasil diskusi. Perwakilan dari setiap kelompok maju mempresentasikan hasil diskusinya, setelah presentasi terlihat ada beberapa siswa yang mengajukan pertanyaan dan menanggapi hasil diskusi.

Ketika kegiatan diskusi dan presentasi suasana kelas menjadi ramai akibat perdebatan antara siswa yang melenceng dari pokok permasalahan yang dibahas, akan tetapi suasana seperti ini yang menjadikan siswa menjadi lebih aktif dalam kelas, sehingga guru harus dapat memberikan solusi yang terbaik dengan membimbing jalannya diskusi agar tidak melenceng dari pokok permasalahan yang sedang dibahas saat itu. Setelah selesai presentasi maka guru bersama dengan siswa menyimpulkan hasil diskusi dan guru menutup pelajaran hari tersebut.

Pada setiap akhir pembelajaran, guru selalu menutup pelajaran dengan penegasan dan pengulangan materi yang kurang dipa- 
hami siswa. Hal ini bertujuan untuk mengulas kembali materi yang telah diberikan. Dengan langkah ini guru akan mengetahui sejauh mana pemahaman siswa terhadap materi yang diajarkan.

Pada pertemuan selanjutnya, seperti pertemuan sebelumnya guru memberikan apersepsi dan motivasi kepada siswa. Kemudian guru menyampaikan materi tentang faktor-faktor yang mempengaruhi integrasi sosial dan faktor-faktor pendorong integrasi sosial. Setelah menyampaikan materi, guru menyuruh siswa untuk duduk sesuai dengan kelompoknya masing-masing kemudian guru memberikan soal untuk didiskusikan. Siswa pun langsung mengerjakan tugas tersebut, mereka langsung berdiskusi dan para tutor mulai menjalankan tugasnya membantu temannya dalam menyelesaikan soal tersebut.

Setelah diskusi selesai, guru menyuruh perwakilan dari masing-masing kelompok untuk maju mempresentasikan hasil diskusi kelompoknya. Kemudian setelah semua kelompok mempresentasikan hasil diskusinya, siswa bersama dengan guru menyimpulkan hasil diskusi. Sebelum mengakhiri pelajaran hari itu guru melakukan refleksi dan mengadakan tanya jawab dengan siswa untuk mengingat materi yang telah dipelajari. Setelah itu guru memberitahukan bahwa minggu depan akan mengadakan ulangan harian dan menyuruh siswa untuk mempersiapkannya.

Dari observasi aktivitas siswa selama kegiatan pembelajaran dapat disimpulkan bahwa siswa telah mampu berdiskusi secara tertib dan proses diskusi berjalan lebih aktif. Siswa semakin terbiasa untuk melakukan diskusi dan presentasi. Peningkatan yang terjadi selama pertemuan pertama sampai dengan pertemuan kelima ini disebabkan siswa sudah terbiasa dengan model pembelajaran yang diterapkan dan tidak terlepas dari semakin meningkatnya aktivitas guru dan siswa. Ibu Sumarni, S.Pd mengatakan:

Pada kegiatan pembelajaran dengan model tutor sebaya ini saya merasa suasana pembelajaran jadi lebih hidup, hal ini dapat dilihat dari banyaknya siswa yang menanggapi permasalahan yang sedang dibicarakan kemudian siswa juga tidak malu-malu lagi untuk menanyakan halhal yang kurang jelas dari penjelasan saya kepada para tutornya." (Wawancara pada hari rabu tanggal 5 Oktober 2010).

Kegiatan diskusi dalam pembelajaran dengan model Tutor Sebaya ini diharapkan agar pembelajaran dapat berlangsung lebih kondusif, siswa lebih aktif dalam pembelajaran serta pembelajaran dapat terlihat lebih hidup sehingga dapat meningkatkan aktivitas siswa di dalam kelas yang nantinya akan mempengaruhi hasil belajar siswa. Tujuan guru melaksanakan kegiatan pembelajaran dengan model Tutor Sebaya ini yaitu agar siswa dapat ikut andil dalam kegiatan pembelajaran, sehingga kegiatan belajar mengajar dapat berjalan dengan baik.

Salah satu tutor, Intan Sueno, mengatakan:

Sebelumnya saya merasa gak yakin Mbak saat ditunjuk sebagai tutor karena kemampuan saya gak seberapa, tapi berkat penambahan materi dan motivasi yang diberikan Bu Marni saya jadi tidak ragu lagi untuk jadi tutor. Saya merasa senang karena bisa membantu teman-teman saya dalam kegiatan diskusi. (Wawancara pada hari Rabu tanggal 12 Oktober 2010).

Secara keseluruhan kegiatan pembelajaran sudah berjalan dengan baik dimana siswa terlibat aktif dalam kegiatan belajar, namun masih perlu adanya motivasi kepada siswa supaya lebih baik dan lebih aktif lagi di dalam kegiatan pembelajaran sehingga hasil belajar dapat lebih optimal lagi. Ika Nur Utami mengatakan:

Setelah beberapa pertemuan dengan model pembelajaran tutor sebaya saya merasa senang mba karena saya bisa menanyakan hal-hal yang kurang saya pahami kepada teman saya sendiri. Kadang saya ingin bertanya pada guru, tapi saya sering merasa malu kepada teman-teman saya. Namun, setelah menggunakan model tutor sebaya ini saya tidak lagi merasa malu karena saya bertanya pada teman saya sendiri dan yang mengetahui pertany- 
aan saya hanya teman-teman satu kelompok saya saja. (Wawancara pada hari Rabu tanggal 12 Oktober 2010).

Hasil wawancara dengan siswa lain yang tidak ditunjuk sebagai tutor Iqbal Alfando berikut:

Saya menjadi lebih berani untuk mengeluarkan pendapat saya mba setelah bu Marni menggunakan model tutor sebaya, kalau ada yang belum dipahami saya jadi lebih enak mengungkapkannya karena dengan teman saya sendiri, saya juga jadi lebih termotivasi untuk belajar. (Wawancara pada hari Rabu tanggal 19 Oktober 2010).

Penerapan model pembelajaran tutor sebaya ini dapat dikatakan berjalan dengan baik, hal ini dapat dilihat dari hasil belajar siswa yang optimal, keaktifan siswa lebih meningkat, dan suasana pembelajaran lebih kondusif. Kinerja guru juga mengalami peningkatan dalam mengelola kegiatan pembelajaran seperti memotivasi siswa untuk lebih aktif bertanya, mengajukan pendapat, menjawab pertanyaan dari guru, dan guru juga lebih sering berkeliling dari satu kelompok ke kelompok yang lain untuk memberikan bimbingan dan arahan kepada siswa.

Penilaian menggunakan teknik tes dan non tes, untuk teknik tes dengan memberikan ulangan harian berupa 20 soal pilihan ganda dan 5 soal uraian, sedangkan teknik non tes yang digunakan berupa lembar observasi aktivitas siswa dalam kegiatan pembelajaran. Selain itu guru biasa membuat catatan pribadi mengenai sikap dan perilaku siswa selama di sekolah. Bu Sumarni, S.Pd tanggal 5 Oktober 2010, beliau mengemukakan:

dalam pemberian nilai kepada siswa selain dari nilai ulangan dan tugas, ibu juga mempunyai catatan pribadi tentang sikap dan perilaku siswa sebagai pertimbangan.

\section{Faktor Pendukung dan Penghambat}

Adanya interaksi antara guru dan sis- wa, pada pelaksanaan pembelajaran bahwa siswa tidak hanya diam, tetapi ikut aktif dengan bertanya dan mengemukakan pendapat. Minat siswa dalam mengikuti pembelajaran cukup tinggi. Hasil tersebut sesuai dengan wawancara yang peneliti lakukan terhadap ibu Sumarni:

Setelah diterapkan model pembelajaran tutor sebaya siswa menjadi lebih aktif karena mereka tidak malu dan takut lagi untuk mengungkapkan halhal yang belum dipahaminya kepada tutor sebaya, sehingga minat belajar siswa semakin meningkat. (Wawancara pada hari Rabu tanggal 12 Oktober 2010).

Guru dan siswa lebih akrab dalam proses pembelajaran sehingga terjadi suasana yang hidup, aktif dan nyaman antara siswa dengan siswa dan siswa dengan guru.

Keterlibatan tutor sebaya dalam kelompok belajar dikelas membuat suasana kelas lebih menarik dan lebih aktif. Hal tersebut sesuai dengan hasil wawancara yang peneliti lakukan terhadap Ibu Sumarni, beliau mengatakan:

Setelah saya lihat dan amati beberapa orang tutor sudah melaksanakan tugasnya dengan baik, mereka dapat menciptakan suasana kelas menjadi lebih menarik dan siswa menjadi lebih aktif. (Wawancara pada hari Rabu tanggal 12 Oktober 2010).

Salah satu hambatan yang muncul dalam pelaksanaan model pembelajaran tutor sebaya ini adalah kurangnya persiapan dari para tutor. Hal ini dikarenakan tidak adanya pelatihan bagi para tutor yang disebabkan oleh kesibukan guru dan alokasi waktu yang terbatas, sehingga para tutor hanya diberikan beberapa tugas oleh guru yang mencakup materi pelajaran sosiologi untuk pertemuanpertemuan selanjutnya. Ada beberapa tutor yang mengaku belum siap untuk menjadi tutor karena mereka merasa belum percaya diri, mereka masih takut ketika membimbing teman-teman satu kelompoknya melakukan 
kekeliruan dalam menjelaskan kembali materi yang telah disampaikan oleh guru. Mereka juga merasa takut jika jawaban yang mereka berikan kepada teman-temannya yang bertanya tidak tepat atau salah. Seperti yang diungkapkan oleh M. Hanif Ibnusholih:

Saya merasa belum siap mba ditunjuk sebagai tutor karena saya takut nantinya memberikan jawaban yang salah atau keliru apabila teman-teman ada yang bertanya, tetapi setelah sering diberikan tugas dan tambahan materi dari Bu Marni saya merasa lebih siap untuk menjadi tutor. (Wawancara pada hari Rabu tanggal 19 Oktober 2010).

Sarana dan prasarana yang kurang memadai juga dapat menghambat kegiatan pembelajaran, seperti yang terjadi di SMA Negeri 1 Tanjung belum adanya Laptop, OHP, dan LCD di ruang kelas. Sehingga apabila guru ingin menggunakan media lebih sering menggunakan media yang konvensional. Bu Sumarni mengatakan:

Di setiap kelas belum dilengkapi dengan Laptop, OHP, LCD sehingga dapat menghambat dalam kegiatan pembelajaran. Jika ingin menggunakan media ibu masih sering menggunakan cara yang konvensional, misalnya jika ingin menampilkan gambar ya ibu mencari gambar tersebut di koran atau di internet kemudian ibu print. (Wawancara pada hari Rabu tanggal 5 Oktober 2010).

Berdasarkan hasil wawancara dengan Ibu Sumarni, beliau mengatakan:

Dalam kegiatan pembelajaran kadang kurang kondusif, hal ini dikarenakan jumlah siswa yang terlalu banyak, dalam pembelajaran model tutor sebaya ini pengaturan siswa dalam kegiatan diskusi terkadang susah untuk dikendalikan, tetapi hal ini tidak menjadi halangan untuk melakukan kegiatan pembelajaran dengan menarik. (Wa- wancara pada hari Rabu tanggal 5 Oktober 2010).

Sulitnya mencari sumber-sumber pembelajaran yang relevan menjadi salah satu penghambat dalam kegiatan pembelajaran, karena siswa kebanyakan tidak mempunyai buku penunjang selain buku modul yang dibeli di sekolah sehingga guru harus berusaha untuk mencari sumber pembelajaran yang menarik dan relevan tentang materi yang akan disampaikan.

Keberhasilan proses belajar mengajar sangat dipengaruhi oleh model pembelajaran yang dilakukan oleh guru. Untuk itu pemilihan model pembelajaran perlu diperhatikan dengan seksama oleh guru sebelum melaksanakan kegiatan pembelajaran. Dalam penelitian ini digunakan model pembelajaran tutor sebaya yang mengarah pada keberhasilan kegiatan pembelajaran. Model pembelajaran ini memberi kesempatan kepada siswa untuk bekerja sendiri dan bekerjasama dengan orang lain, sehingga siswa dilatih untuk lebih peduli kepada orang lain.

Pada pembelajaran tutor sebaya guru berfungsi sebagai fasilitator yaitu memberikan pengarahan sepenuhnya kepada siswa, yang lebih ditekankan pada pembelajaran ini adalah keaktifan siswa. Dengan adanya keaktifan tersebut akan menumbuhkan motivasi belajar yang tinggi pada siswa dan pada akhirnya akan mempengaruhi hasil belajar siswa (Annuur, 2009:67).

Menurut Akrom (dalam Rachmiati, 2010:19) perencanaan pembelajaran menggunakan model tutor sebaya antara lain yaitu: 1) membuat program, guru membuat program pengajaran satu pokok bahasan yang berisi materi-materi pokok yang akan disampaikan oleh guru pada tiap-tiap pertemuan, selain itu juga mencakup rencana kegiatan yang akan dilakukan pada kegiatan pembelajaran, 2) menyiapkan tutor, guru menunjuk tujuh orang siswa sebagai tutor sesuai dengan jumlah kelompok yang telah dibentuk, dan 3) Pemberian tugas kepada para tutor, guru memberikan tugas kepada para tutor terlebih dahulu sebelum tutor-tutor tersebut memberikan bimbingan kepada teman-temannya, tugas tersebut berupa per- 
tanyaan-pertanyaan atau permasalahan yang mencakup materi pelajaran untuk pertemuan-pertemuan selanjutnya.

Pada saat pembelajaran dengan model tutor sebaya berlangsung siswa terlihat lebih semangat dan antusias serta lebih termotivasi untuk lebih semangat belajar. Penelitian yang dilakukan secara kolaborasi antara peneliti dengan guru sosiologi menyatakan bahwa dalam proses pembelajaran sosiologi dengan menerapkan model pembelajaran tutor sebaya telah memberikan dorongan kepada guru sosiologi dalam melakukan pembelajaran yang mengikutsertakan siswa didalamnya.

Dengan adanya model pembelajaran ini dapat melatih siswa bertanggung jawab untuk menyelesaikan tugasnya masing-masing dan dapat mengembangkan keterampilan menjalin hubungan antar siswa. Hal ini dapat dilihat dari setiap siswa telah mampu menyelesaikan tugasnya masing-masing, para tutor sudah bisa memberikan bimbingan kepada teman-teman satu kelompoknya sehingga dapat membantu siswa yang lainnya. Selain itu, dengan penerapan model pembelajaran ini dapat mengembangkan keterampilan menjalin hubungan antar siswa. Hal ini dapat dilihat dari komunikasi antara siswa yang satu dengan yang lain mengalami peningkatan, sehingga baik siswa yang termasuk pandai di kelasnya maupun siswa yang biasa-biasa saja atau kurang pandai dapat berkomunikasi dengan baik, tidak ada lagi perasaan minder untuk bertanya kepada temannya yang mempunyai prestasi lebih tinggi darinya.

Selain melatih siswa bertanggung jawab untuk menyelesaikan tugasnya masingmasing dan dapat mengembangkan keterampilan menjalin hubungan antar siswa, proses tutorial ini juga mempunyai manfaat yang lain. Menurut Djamarah (1995:30) manfaat tersebut antara lain: 1) ada peningkatan hasil belajar bagi siswa yang enggan bertanya atau takut pada gurunya, sehingga dengan adanya tutorial ini diharapkan siswa dapat leluasa bertanya pada temannya sendiri, 2) mempererat hubungan antara sesama teman sehingga rasa sosialnya semakin kuat, 3) bagi tutor akan memperkuat konsep yang telah diterima, karena dengan mengajarkan kembali pada siswa yang lain maka ia akan belajar, 4) para tutor memperoleh kesempatan untuk melatih diri memegang tanggung jawab dalam mengemban suatu tugas dan melatih kesabaran.

Selama proses penelitian berlangsung tanggapan guru terhadap pembelajaran sosiologi dengan menggunakan model tutor sebaya cukup baik. Hal ini dapat dilihat dari kualitas pembelajaran yang terus meningkat pada tiap pertemuan. Peningkatan kualitas pembelajaran terjadi secara bertahap pada awal sampai akhir pertemuan yang pada akhirnya dapat meningkatkan hasil belajar siswa. Sebagaimana yang dikatakan oleh Huda (2009:81) bahwa salah satu kelebihan Model tutor sebaya adalah dapat meningkatkan prestasi akademik dan kemampuan sosial siswa.

Menurut Annnuur (2009:66) pembelajaran dengan tutor sebaya ini memberikan kontribusi hasil belajar yang lebih baik, hal ini dapat dilihat dari meningkatnya hasil belajar siswa. Karena dalam pembelajaran tutor sebaya kelas dibagi dalam beberapa kelompok kecil untuk berdiskusi, sehingga terjadi interaksi tatap muka dan keterampilan dalam menjalin hubungan antar personal. Pada pembelajaran ini lebih mengutamakan adanya kerja sama dan komunikasi yang baik antar siswa, selain itu dalam pembelajaran tutor sebaya juga terdapat sistem gotong royong yang dapat memunculkan dampak positif terhadap aktivitas dan hasil belajar siswa, sebab siswa akan merasa nyaman mendapat bantuan dari teman lainnya daripada oleh gurunya. Keberhasilan yang dicapai tercipta juga karena hubungan antar siswa yang saling mendukung, saling membantu dan peduli. Siswa yang lemah mendapat masukan dari siswa yang lebih kuat, sehingga menumbuhkan motivasi belajarnya.

Berdasarkan hasil pengamatan kinerja guru dan aktivitas siswa saat pembelajaran menggunakan model pembelajaran tutor sebaya dapat berjalan dengan baik. Hal ini dapat dibuktikan dengan penerapan model pembelajaran tutor sebaya dapat meningkatkan aktivitas belajar siswa dan juga hasil belajar siswa pada mata pelajaran sosiologi. 
Selain itu, model pembelajaran tutor sebaya juga dapat meningkatkan aktivitas siswa dalam mengikuti pelajaran serta memberikan nilai tambah bagi siswa untuk mengambil sikap dalam kegiatan diskusi di kelas.

Berdasarkan hasil wawancara dengan ibu Sumarni, S.Pd yang berkaitan dengan penerapan model pembelajaran tutor sebaya menyatakan bahwa model pembelajaran tersebut sangat baik diterapkan karena dapat memacu keaktifan dan komunikasi antar siswa. Tingkat keaktifan siswa yang meningkat disebabkan karena siswa termotivasi oleh temannya, proses pembelajaran yang menyenangkan membuat siswa lebih paham terhadap materi yang disampaikan oleh guru dan hal tersebut berdampak terhadap nilai atau hasil belajar siswa yang meningkat.

Dalam penerapan model pembelajaran tutor sebaya di SMA Negeri 1 Tanjung ini terdapat beberapa faktor yang mendukung dan menghambat pelaksanaan model pembelajaran tutor sebaya. Faktor-faktor pendukung tersebut antara lain yaitu: 1) adanya interaksi antara guru dan siswa, 2) minat siswa dalam mengikuti pembelajaran cukup tinggi, 3) guru dan siswa lebih akrab dalam proses pembelajaran sehingga terjadi suasana yang hidup, aktif dan nyaman antara siswa dengan siswa dan siswa dengan guru, dan 4) keterlibatan tutor sebaya dalam kelompok belajar dikelas membuat suasana kelas lebih menarik dan lebih aktif.

Selain faktor pendukung, terdapat juga faktor-faktor yang menghambat pelaksanaan model pembelajaran tutor sebaya adalah: 1) kurangnya persiapan dari para tutor, hal ini disebabkan waktu yang terbatas sehingga tidak diadakan pelatihan bagi para tutor, 2) sarana dan prasarana yang kurang memadai, salah satunya disebabkan belum adanya sarana dan prasarana penunjang seperti laptop, LCD, dan OHP yang ada di ruang kelas. Sehingga saat guru akan menggunakan media harus menggunakan media yang masih konvensional, 3) kegiatan pembelajaran yang kurang kondusif, hal ini dapat dilihat dari jumlah siswa yang terlalu banyak, sehingga dalam pembelajaran model tutor sebaya pengaturan siswa dalam kegiatan diskusi kadang susah untuk dikendalikan, 4) sumber belajar yang kurang memadai, hal ini dapat dilihat dari siswa hanya menggunakan buku modul sebagai pegangannya sehingga guru harus berusaha untuk mencari sumber pembelajaran lain yang relevan dan menarik tentang materi yang akan disampaikan, diantaranya yaitu dengan mengambil dari buku paket sosiologi dan artikel-artikel yang ada hubungannya dengan materi sosiologi yang didapat dari internet.

\section{SIMPULAN}

Berdasarkan hasil dan pembahasan, maka dapat disimpulkan sebagai berikut. Dalam penerapan model pembelajaran tutor sebaya ini memerlukan perencanaan yang lebih matang, karena dalam perencanaan tersebut mencakup beberapa tahapan antara lain dengan membuat program, menyiapkan tutor, dan memberikan tugas kepada para tutor. Selain itu guru juga memberikan beberapa materi tambahan yang diambil dari berbagai sumber, baik dari buku paket yang lainnya maupun dari internet.

Pada pelaksanaan model tutor sebaya ini suasana kegiatan pembelajaran menjadi lebih hidup, hal ini dapat dilihat dari banyaknya siswa yang menanggapi permasalahan yang sedang dibicarakan kemudian siswa juga tidak malu-malu lagi untuk menanyakan hal-hal yang kurang jelas dari penjelasan guru kepada para tutornya. Terdapat beberapa faktor yang mendukung dan menghambat dalam pelaksanaan model tutor sebaya yaitu sebagai berikut, untuk faktor pendukung antara lain: 1) adanya interaksi antara guru dan siswa, 2) minat siswa dalam mengikuti pembelajaran cukup tinggi, 3) guru dan siswa lebih akrab dalam proses pembelajaran sehingga terjadi suasana yang hidup, aktif dan nyaman antara siswa dengan siswa dan siswa dengan guru, dan 4) keterlibatan tutor sebaya dalam kelompok belajar dikelas membuat suasana kelas lebih menarik dan lebih aktif. Sedangkan faktor penghambatnya adalah: 1) kurangnya persiapan dari para tutor, 2) sarana dan prasarana yang kurang memadai, salah satunya disebabkan belum adanya sarana dan prasarana penunjang seperti laptop, LCD, dan OHP yang ada di 
ruang kelas, 3) kegiatan pembelajaran yang kurang kondusif, hal ini dikarenakan jumlah siswa yang terlalu banyak, 4) sumber belajar yang kurang memadai, hal ini dapat dilihat dari siswa hanya menggunakan buku modul sebagai pegangannya sehingga guru harus berusaha untuk mencari sumber pembelajaran lain yang relevan dan menarik.

\section{DAFTAR PUSTAKA}

Ahmadi, A. dan Supriyono, W. 2004. Psikologi Belajar. Jakarta: PT Rineka Cipta

Annuur, L. 2009. Efektivitas Metode Tutor Sebaya untuk Meningkatkan Hasil Belajar Siswa Pada Mata Pelajaran Geografi Pokok Bahasan Unsur-unsur Fisik Wilayah Indonesia Kelas VIII Semester 1 SMPN 2 Patebon-Kendal Tahun 2008/2009. Skripsi. Semarang: FIS UNNES

Depdiknas. 2003. Kompetensi Berbasis Kompetensi. Jakarta: Departemen Pendidikan Nasional

Djamarah, S.B. 2006. Strategi Belajar Mengajar. Jakarta: PT Rineka Cipta

Huda, A.Q. 2009. Penerapan Model Pembelajaran Cooperative Learning Tipe Peer Tutoring (Tutor Sebaya) untuk Meningkatkan Hasil Belajar IPS Kompetensi Dasar Hidrosfer Siswa Kelas VII SMPN 07 Kota Semarang Tahun Ajaran 2008/2009. Skripsi. Semarang: FIS UNNES

Milles, B.M. \& Huberman, A.M. 1992. Analisis Data Kualitatif. Jakarta: UI Press

Moleong, Lexy. 2007. Metodologi Penelitian Kualitatif. Bandung: PT. Remaja Rosdakarya

Muntasir. 2007. Penerapan metode tutor sebaya dalam mengoptimalkan pembelajaran (online), http://smkswadayatmg.wordpress. com/27/09/2007. (diakses tanggal 18 Desember 2007)

Rachmiati, T. 2010. Penggunaan Model Pembelajaran Tutor Sebaya dalam Kelompok Kecil untuk Meningkatkan Kualitas Pembelajaran Akuntansi Siswa kelas XI SMA Negeri 3 Surakarta. Skripsi. Surakarta: Universitas Sebelas Maret

Sawali. 2009. Diskusi Kelompok Terbimbing Model Tutorial Sebaya. (online), http://sawali. info/2009. (diakses tanggal 3 Mei 2009)

Semiawan, C., dkk. 1992. Pendekatan Keterampilan Proses. Jakarta: PT Grasindo (Gramedia Widiasarana Indonesia)

Silberman, M. 2001. Active Learning: 101 Strategi Pembelajaran Aktif. Yogyakarta: Yappendis (Yayasan Pengkajian dan Pengembangan Ilmu-ilmu Pendidikan Islam)

Spradlay, J.P. 2006. Metode Etnografi. Yogyakarta: Tiara Wacana

Sudjana, N. 2009. Dasar-dasar Proses Belajar Mengajar. Bandung: Sinar Baru Algensindo

Sugiyono. 2009. Metode Penelitian Pendidikan: Pendekatan Kuantitatif, Kualitatif, dan R\&D. Bandung: Alfabeta

Suherman, E. 2003. Strategi Pembelajaran Matematika Kontemporer. Bandung: UPI

Supratman, D. 2007. Proses Pendidikan Tuntas (Modelmodel Pembelajaran dalam Strategi Portofolio). Semarang: UNNES

Suprijono, A. 2009. Cooperative Learning Teori dan Aplikasi Paikem. Yogyakarta: Pustaka Pelajar

Tim Penyusun Kamus Pusat Bahasa. 2002. Kamus besar Bahasa Indonesia. Jakarta: Balai Pustaka

Winataputra, U.S. 2000. Pembelajaran Kelas Rangkap (PKR). Depdikbud

Wirawan, A. 2010. Pengembangan Pembelajaran Inkuiri Sosial Pada Materi Interaksi Sosial Sosiologi. Jurnal Komunitas, 2 (2): 97-105 